\title{
Role of Research and Development in Smart Specialisation of EU regions and its Effect on Labour Productivity
}

\author{
Peter PISÁR, Ján HUŇADY, Ina DURČEKOVÁ \\ Matej Bel University in Banská Bystrica, Banská Bystrica, Slovakia \\ \{peter.pisar, jan. hunady, ina.durcekova\} @umb.sk
}

\begin{abstract}
Regional development and its role in the context of economic growth of the country has been gaining more attention in the last decades. European Union has been shifting its attention towards regional development which reflects in the new strategy called Smart Specialisation. One of the important driving forces of regional growth is research and development. Higher education institutions play important role in this area as well as in the development of human capital in the region. We firstly compared NUTS 2 regions in the Czech Republic and Slovakia and according to selected indicators of research and development. We also applied cluster analysis in order to classify similar regions into same clusters. The main aim of our research is to test potential link between intensity of research and development within the concept of smart specialisation of the region and labour productivity in the region. We used factor analysis and regression analysis based on the data crosssectional data for all NUTS 2 regions in the EU. Our results suggest that focus on research and development within the region is positively correlated with higher labour productivity. More scientific publications and patents are positively linked to higher productivity in the region.
\end{abstract}

Keywords: Research \& Development, EU regions, Labour Productivity, Smart Specialisation, Higher education.

\section{Introduction}

Research and development are becoming more important and gaining more attention in the light of globalization and effort to increase economic performance and competitiveness. The intensity of research and development could be seen as one of the most important factors supporting the innovation performance of the region or whole country. We can further say that innovation are a driving force that helps increase labour productivity in the business and public sector. Thus, it is likely that research and development activities within the region could be beneficial for regional economy and its citizens in several ways. Potential increase in labour productivity due to the innovation may result in further economic growth and in turn help improve lives of the citizens. The importance of innovation and $R \& D$ is reflected in policies of individual countries as well as transnational unions such as European Union, which 
are shifting their focus towards policies aimed at research and development and support of innovation at regional and national level. Smart specialisation of the regions is one of the EU regional strategies which are closely related to support of innovation at regional level.

Our paper aims to test potential link between intensity of research and development within the concept of smart specialisation of the region and labour productivity in the region. We assume that EU regions are specialised more on services and especially those with more intensive research and technology activities have higher labour productivity. Moreover, we examine several indicators related to regional smart specialisation and classify NUTS 2 in the Czech Republic and Slovakia based on these indicators into clusters. In the next section we describe the concept of smart specialisation with the focus on research and development. In further sections we describe the methodology of research and present the most important results.

\section{$2 \quad$ Literature review}

In the last decades, there have been numerous publications and policy outlines that stress the importance of knowledge and innovation policy for the European Union. There is no doubt about the importance of technology, knowledge and innovation for the competitiveness and economic power of a country. [12] Research and innovation provide us with the knowledge and solutions to deal with urgent problems as well as long-term societal challenges. [7] This rationale is shown in Europe 2020 strategy established by European Commission focused on smart, sustainable and inclusive growth in the EU countries. The Europe 2020 has five main goals including employment, climate change and energy, education, poverty and social exclusion and research and development. As can be seen from the priorities of European Commission, research and development are one of the important elements of sustaining growth. There are many projects and concepts focused on supporting innovation, research and development on national or transnational levels. However, focusing on research and development on regional level is equally important as has been proven by various studies. Project KIT (Knowledge - Innovation - Territory), which involved participation of many important universities, proved that „one-sizefits-all" approach is not suitable for constructing innovation policies. KIT studies show that it is important to view innovation policy in wider context than support of research as well as the fact that individual regions have different needs related to innovation policy.

One of the concepts designed to support innovation, research and development in EU countries on regional level is new concept of European Commission called Smart specialisation. The main aim of the smart specialisation is to increase innovation performance of EU countries. This concept is partly based to advance on understanding of relationships between economic geography, technology and institutions [14]. Smart specialisation is a place-based approach characterised by the identification of strategic areas for intervention based on the analysis of the strengths and potential of the economy and on an Entrepreneurial Discovery Process (EDP). Smart specialisation strategies are based on „bottom-up“ approach considering defining priorities rather than traditional industrial policies. Other elements of smart 
specialisation strategies are transparency (including evaluation and monitoring) and flexibility.

National/Regional Research and Innovation Strategies for Smart Specialisation focus on five points:

- the focus of policy support and investment is on key national/regional priorities, challenges and needs for knowledge-based development,

- strategies are based on each country/region's strengths, competitive advantages and potential poor excellence,

- support is divided between technological and practice-based innovation and aimed at stimulation of private sector investment,

- stakeholders are fully involved and innovation and experimentation is encouraged,

- strategies are evidence-based and include sound monitoring and evaluation systems. [6]

Key elements of smart specialisation are reflected in these principles:

- smart specialisation is a place based approach, it builds on the assets available to regions and on their specific socio-economic challenges,

- member states and regions should support only a limited number of priorities for knowledge-based investments/clusters,

- setting priories should not be a top-down process, it should be inclusive process of stakeholders' involvement centred on entrepreneurial discovery,

- strategy should take into account broad view of innovation, meaning it should support both technological and practice based and social innovation,

- strategy should include good monitoring and evaluation system. [8]

Considering limited public resources, it seems to be very important to focus support of public resources to R\&D areas that contribute to economic growth of the country or areas that have potential. [3] The spatial distribution of R\&D expenditures among the regions has been examined so far in the EU countries [13] as well as in other countries such as for example in China. [15], [17] Zachariadis [16] argued that $\mathrm{R} \& \mathrm{D}$ expenditure is mostly reflected in the number of patents and patents have a positive effect on the development of technologies, which raises economic growth.

Performance of countries as well as regions is closely linked to labour productivity. There have been many studies directed at finding link between innovation, R\&D and productivity. There was established correlation and plausible causality between innovation policies and labour productivity growth. [1] Some studies were also focused on impact of research and development and innovation policies on labour productivity on sectoral level. [4] It was proven that R\&D and ICT contribute to innovation to a different extent with $R \& D$ being the most relevant input for innovation. Furthermore, universities appear to play very important role in creating high-tech innovation in the region. [2]

It was also shown that both R\&D and ICT individually appear to have large impacts on productivity. [10] Privately financed industrial R\&D was proved to have significant effects on productivity growth of manufacturing industries with industries directly conducting the privately financed $R \& D$ having larger effect than industries indirectly purchasing capital from industries conducting privately financed R\&D. [11] The study investigating long-term effects of various types of $R \& D$ on multi-factor 
productivity growth showed that increase of 1 per cent in business R\&D generated 0.13 per cent in productivity growth with effect being larger in countries with intensive business R\&D and lower share of defence-related government spending. [9] Research studying relationship between total factor productivity, R\&D, human capital and public infrastructure showed that regional productivity is positively affected by R\&D activity and public infrastructure of neighbouring regions. [5]

\section{$3 \quad$ Methodology and data}

As stated in the introduction, the main aim of the paper is to test potential link between intensity of research and development within the concept of smart specialisation of the region and labour productivity in the region. In our analysis we used data from Eurostat database. The dataset consists of 276 cross-sectional observations for each NUTS 2 region in the EU. Most of the observations are valid for the year 2015. All variables used in the analysis are described in more detail in Table 1.

Table 1. Description of variables used in the analysis

\begin{tabular}{l|l} 
Variable & Short description \\
\hline Labour productivity & $\begin{array}{l}\text { Wage adjusted labour productivity } \\
\text { It is defined as value added divided by personnel costs } \\
\text { which is subsequently adjusted by the share of paid } \\
\text { employees in the total number of persons employed, or } \\
\text { more simply, apparent labour productivity divided by } \\
\text { average personnel costs (expressed as a ratio in \%). }\end{array}$ \\
\hline Factor 1 & $\begin{array}{l}\text { Factor 1 get from the factor analysis of employment } \\
\text { structure by type of the economic activity }\end{array}$ \\
\hline Factor 2 & $\begin{array}{l}\text { Factor 2 get from the factor analysis of employment } \\
\text { structure by type of the economic activity }\end{array}$ \\
\hline Population with tertiary & $\begin{array}{l}\text { Population aged 25-64 with higher educational attainment } \\
\text { (ISCED 5-8). NUTS 2 regions (\%) }\end{array}$ \\
\hline Scientific publications & $\begin{array}{l}\text { Publications per million inhabitants. ScienceMetrix } \\
\text { calculations, based on Scopus data }\end{array}$ \\
\hline GDP per capita & $\begin{array}{l}\text { GDP per capita based on purchasing power parity (PPP). It } \\
\text { is gross domestic product converted to international dollars } \\
\text { using purchasing power parity rates. }\end{array}$ \\
\hline $\begin{array}{l}\text { Employment in } \\
\text { technology and } \\
\text { knowledge-intensive }\end{array}$ & $\begin{array}{l}\text { Employment in technology and knowledge-intensive } \\
\text { sectors by NUTS 2 (high-technology manufacturing and } \\
\text { knowledge-intensive high-technology services) } \% \text { of total } \\
\text { employment }\end{array}$ \\
\hline Patent applications & $\begin{array}{l}\text { Number of patent applications to the EPO per million } \\
\text { inhabitants }\end{array}$ \\
\hline employment & $\begin{array}{l}\text { Core Creativity Class employment \% of population aged } \\
15-64\end{array}$ \\
\hline
\end{tabular}




\begin{tabular}{l|l}
\hline Access to Internet & $\begin{array}{l}\text { Households with access to the Internet at home ( \% of total } \\
\text { households) }\end{array}$ \\
\hline Motorways & $\begin{array}{l}\text { Population living in surrounding regions weighted by } \\
\text { travel time along motorways }\end{array}$ \\
\hline Corruption & Corruption is a major problem (\% of respondents) \\
\hline $\begin{array}{l}\text { HR in Science and } \\
\text { technology }\end{array}$ & $\begin{array}{l}\text { Persons with tertiary education and employed in science } \\
\text { and technology \% of active population }\end{array}$ \\
\hline GERD total & $\begin{array}{l}\text { Gross domestic expenditure on R\&D (GERD) (Euro per } \\
\text { inhabitant) }\end{array}$ \\
\hline GERD higher education & $\begin{array}{l}\text { Gross domestic expenditure on R\&D (GERD) financed by } \\
\text { higher education (Euro per inhabitant) }\end{array}$ \\
\hline
\end{tabular}

Source: Authors based on the data from Eurostat (European Commission, 2017).

We strategically chose especially variables related to research and development. Firstly, we examined selected indicators related to smart specialization focused on research and development in the NUTS 2 regions of the Czech Republic and Slovakia. We analysed six indicators (GERD by High education, Patents, Scientific publications, access to internet, creative class employment and employment in technology and knowledge-intensive industry) transformed to the same scale and compared the regions in Slovakia and the Czech Republic separately. Moreover, based on these indicators we performed cluster analysis in order to classify regions in the Czech Republic and Slovakia to the clusters according to similarity in smart specialization in science and technology. We used group average distance between clusters and the Ward method of clustering.

Next, we focused our attention on the classification of employment by economic activity in EU (NUTS 2) regions. This could be also used as the proxy for specialization of region. We decided to perform factor analysis based on these indicators to identify potential hidden factors that could be reported as specialization of the region. We got two main factors based on this method which were further used in regression analysis as independent variables together with other variables described in Table 1. On the other hand, indicator capturing the labour productivity was used as dependent variable in all regression models. Regression models have been tested for autocorrelation and data have been tested for multicolinearity. Standard errors have been estimated with standard errors corrected for heteroscedasticity.

\section{$4 \quad$ Results}

Smart specialization of the region could be aimed on increasing the intensity of research and development within the region in order to increase innovation potential. We analysed six selected indicators transformed to same scale. All indicators are related to research and development activities within regions in the Czech Republic and Slovakia. The performance of NUTS 2 regions of Czech Republic is shown in Figure 1. As we can see the region Prague is performing the best in five out of six dimensions. However, the region Střední Čechy is virtually at the same level in almost every indicator except GERD by higher education sector, which is 
significantly lower in Střední Čechy. On the other hand, region Severozápad seems to be significantly lagging behind other regions in almost every aspect.

We also perform similar analysis for NUTS 2 regions in Slovakia. Results are graphically illustrated in Figure 2. Similarly as in the case of the Czech Republic, the metropolitan area of capital town is performing the best in most indicators. Furthermore, in this case other regions are lagging even more behind top performing region. Internet access is the only one dimension where region Východné Slovensko slightly outperforms Bratislavský kraj. All three regions except Bratislavský kraj are at similar level in all other five dimensions.

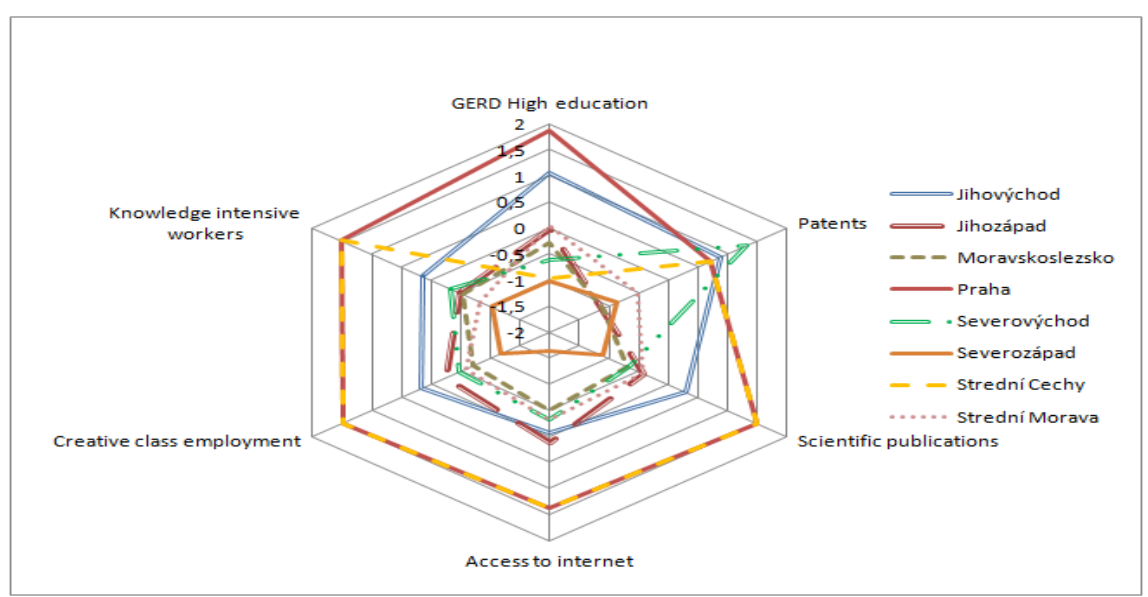

Fig. 1. Indicators of research and development in NUTS 2 in the Czech Republic

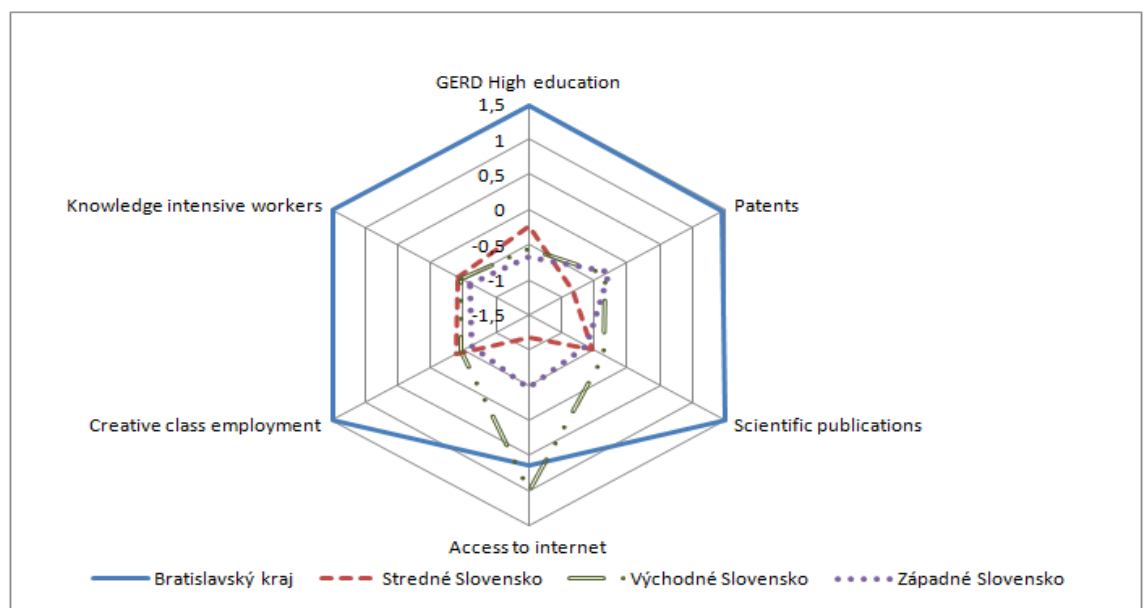

Fig. 2. Selected indicators of research and development in NUTS 2 in Slovakia 
Furthermore, we used cluster analysis in order to classify all NUTS2 regions according to the six indicators mentioned above. We applied Ward method of clustering. As it can be seen in the Dendrogam (Figure 3) regions Praha and Bratislavský kraj are in the same cluster. Moreover, region Stredni Čechy is also similar to these. All three regions are the best performing ones with respect to research and development activities. Other three regions from Slovakia are classified in the same cluster. On one hand, regions Moravskoslezko, Strední Morava and Jihozápad are in one cluster and regions Jihovýchod a Sverovýchod can be classified in another cluster.

In the next part of the analysis we focus our attention on the structure of the employment according to the different economic activities. We assume that the type of the regional specialisation could be reflected by the employment structure. We further used factor analysis, in order to reduce this information to one or two variables as well as to capture unobserved factor which in this case could mean regional specialisation.

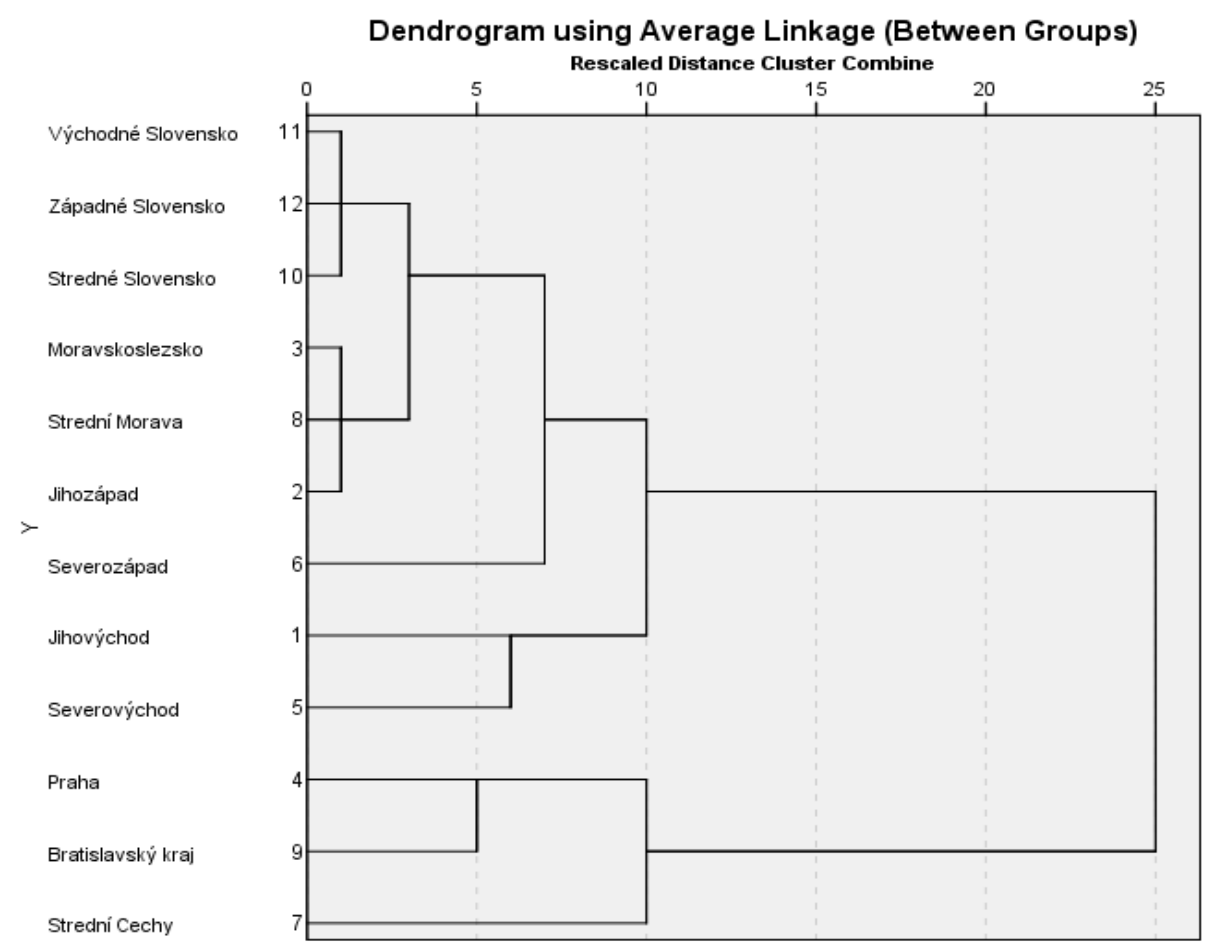

Fig. 3. Dendrogram of NUTS 2 regions based on selected indicators of research and development

Using the factor analysis based on the share of employment in ten different economic activities we get two main factors. These two factors have been chosen according to the eigenvalue higher than 1 as we can see in Figure 4. Both factors capture together more than $95 \%$ of the variability of previous 10 variables. 


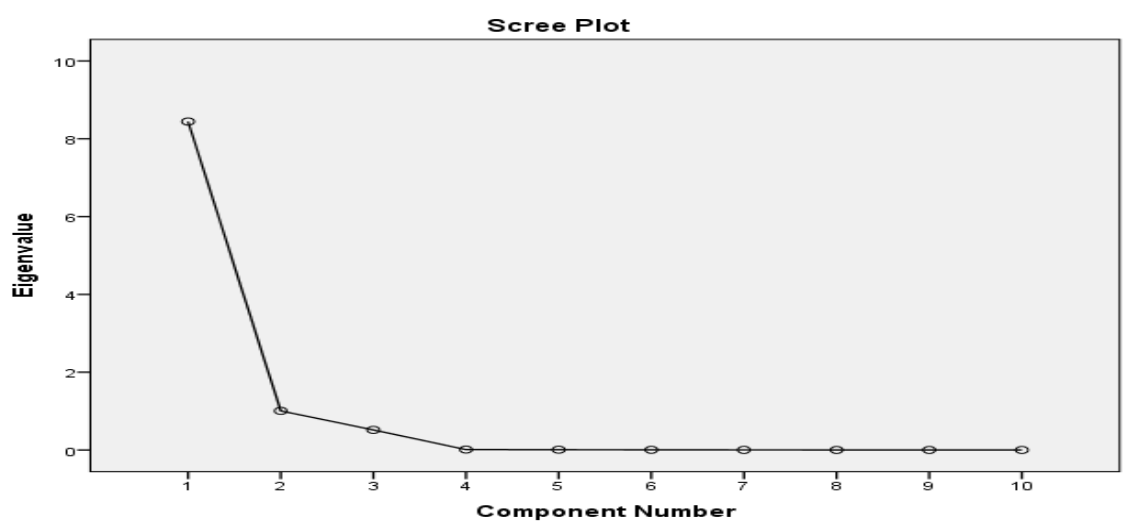

Fig. 4. Scree plot of factors from factor analysis based on eigenvalues Source: Authors.

Table 2 shows the results of factor analysis in the form of rotated component matrix. Factor 1 is positively correlated with employment in services and manufacturing. This could also very likely mean better environment for further smart specialization and innovation. On the other hand Factor 2 represents mostly regional specialization on agriculture.

Table 2. Rotated Component Matrix from factor analysis

\begin{tabular}{lrr}
\hline Employment by economic activity: & \multicolumn{2}{c}{ Component } \\
\cline { 2 - 3 } & Factor 1 & Factor 2 \\
\hline 1. Agriculture, forestry and fishing &, 001 &, 998 \\
\hline 2. Mining and quarrying &, 749 &, 087 \\
\hline 3. Manufacturing &, 991 &, 008 \\
\hline 4. Wholesale and retail trade &, 997 &, 011 \\
\hline 5. Information and storage &, 990 &,- 012 \\
\hline 6. Financial and insurance activities &, 991 &,- 030 \\
\hline 7. Real estate activities &, 988 &, 004 \\
\hline 8. Professional, scientific and technical activities &, 992 &,- 024 \\
\hline 9. Public administration &, 996 &,- 024 \\
\hline 10. Art, entertainment and recreation &, 994 &,- 024 \\
\hline
\end{tabular}

Note: We used Factor analysis with Principal Component Analysis extraction method and Varimax rotation with Kaiser Normalization.

Both factors regarding the type of regional specialization that we got from factor analysis have been further used in the regression analysis as independent variables. Hence, we want to examine whether regional specialization and research and development activities located within the region could have some positive 
consequences on labour productivity in the region. The results of regression models are summarized in Table 3.

Table 3. Results of panel regression models of „Labour productivity“

\begin{tabular}{|c|c|c|c|c|c|}
\hline & 1.1 & 1.2 & 1.3 & 1.4 & 1.5 \\
\hline $\mathrm{C}$ & $\begin{array}{l}23.98 \\
(0.79) \\
\end{array}$ & & & & \\
\hline Factor 1 & $\begin{array}{l}4.46 * * * \\
(2.93)\end{array}$ & $\begin{array}{l}4.41 * * \\
(2.06) \\
\end{array}$ & & & \\
\hline Factor 2 & $\begin{array}{l}-4.51 * * \\
(-2.02)\end{array}$ & $\begin{array}{l}6.50 * * \\
(14.31) \\
\end{array}$ & & & \\
\hline $\begin{array}{l}\text { Log(GDP per } \\
\text { capita) }\end{array}$ & $\begin{array}{l}4.15 \\
(1.37) \\
\end{array}$ & $\begin{array}{l}6.50 * * * \\
(14.31)\end{array}$ & $\begin{array}{l}2.34 \\
(1.2) \\
\end{array}$ & $\begin{array}{l}2.93^{*} \\
(1.72) \\
\end{array}$ & $\begin{array}{l}4.25 * * * \\
(5.47)\end{array}$ \\
\hline $\begin{array}{l}\text { Population } \\
\text { with tertiary } \\
\text { education }\end{array}$ & $\begin{array}{l}0.37 * * \\
(1.99)\end{array}$ & $\begin{array}{l}0.38 * * \\
(2.06)\end{array}$ & $\begin{array}{l}0.45 * * * \\
(2.15)\end{array}$ & $\begin{array}{l}0.25 \\
(1.22)\end{array}$ & $\begin{array}{l}0.73 * * * \\
(3.99)\end{array}$ \\
\hline $\begin{array}{l}\text { Scientific } \\
\text { publications }\end{array}$ & $\begin{array}{l}0.01 * * * \\
(3.69)\end{array}$ & $\begin{array}{l}0.01 * * * \\
(3.54)\end{array}$ & $\begin{array}{l}0.01 * * * \\
(3.40)\end{array}$ & $\begin{array}{l}0.01 * * \\
(2.44) \\
\end{array}$ & \\
\hline $\begin{array}{l}\text { Patent } \\
\text { applications }\end{array}$ & $\begin{array}{l}0.03 * * * \\
(3.69) \\
\end{array}$ & $\begin{array}{l}0.035 * * * \\
(3.36) \\
\end{array}$ & & & \\
\hline Corruption & $\begin{array}{l}0.18 \\
(0.11) \\
\end{array}$ & $\begin{array}{l}0.11 \\
(0.07) \\
\end{array}$ & & & \\
\hline Motorways & $\begin{array}{l}0.09 * * * \\
(5.71)\end{array}$ & $\begin{array}{l}0.10^{* * *} \\
(5.76) \\
\end{array}$ & $\begin{array}{l}0.11 * * * \\
(3.75) \\
\end{array}$ & $\begin{array}{l}0.10 * * \\
(2.59) \\
\end{array}$ & $\begin{array}{l}0.13 * * * \\
(8.60)\end{array}$ \\
\hline $\begin{array}{l}\text { Access to } \\
\text { internet }\end{array}$ & & & $\begin{array}{l}0.48 * \\
(1.80) \\
\end{array}$ & $\begin{array}{l}0.45^{*} \\
(1.75) \\
\end{array}$ & \\
\hline $\begin{array}{l}\text { GERD higher } \\
\text { education }\end{array}$ & & & $\begin{array}{l}0.01 * * \\
(2.22)\end{array}$ & & \\
\hline GERD total & & & & $\begin{array}{l}0.01 \\
(1.42) \\
\end{array}$ & \\
\hline $\mathrm{R}^{2}$ & 0.53 & 0.53 & 0.44 & 0.47 & 0.44 \\
\hline Adjusted $\mathrm{R}^{2}$ & 0.52 & 0.52 & 0.42 & 0.45 & 0.43 \\
\hline DW stat & 1.90 & 1.89 & 2.08 & 1.56 & 1.83 \\
\hline Akaike crit. & 8.71 & 8.70 & 8.98 & 9.03 & 8.89 \\
\hline Observations & 261 & 261 & 173 & 162 & 265 \\
\hline
\end{tabular}

Note: Labour productivity in the regions has been used as dependent variable in all models.

Standard errors have been corrected for heteroscedasticity. (.) denotes t-statistics, */**/*** mean significance at the $10 \% / 5 \% / 1 \%$ levels of significance.

We used several independent variables related to research and development such as Gross domestic expenditure on R\&D and the number of scientific publications and patent applications per capita. Furthermore, we also used several control variables such as GDP per capita, proxy for the quality of institutional environment (corruption) as well as proxies for quality of infrastructure. The share of tertiary educated people 
could be seen on one hand as the indicator related to higher education and research but on the other hand it could be also used as the proxy for human capital in the region. We applied together five models with different independent variables in order to check for robustness of the results and to eliminate potential correlations between variables.

Based on the results we can say that specialisation of the region on services and manufacturing is positively related to higher labour productivity. On contrary, regions with more employees in agriculture, forestry and fishing resulted in average lower labour productivity. The result is expected and it stems from the very nature of these activities.

The results strongly suggest that especially scientific publications, patent applications and gross domestic expenditure on R\&D (GERD) financed by higher education could have positive effect on labour productivity in the region. These results are complementary to findings of several previous studies [10].

Inputs of research as well as outputs of the research could be seen as important part of smart specialisation. Furthermore, there is another way of how universities and higher education institutions could increase labour productivity. Higher education institutions play prominent role in increasing educational level in the region, which in turn could positively influence the labour productivity. This assumption has been supported by our results. The share of population with tertiary education seems to positively correlate with labour productivity. This variable has been significant at least at 5\% level in four out of five models. Moreover, we also found relatively strong evidence that the quality of infrastructure in the region could play very important role in increasing labour productivity which is mostly in line with previous studies [5].

\section{Conclusion}

The implementation of regional smart specialisation could be important step in order to improve regional development in the EU. Research and development should play important role in this process. Base on the theory and previous empirical research we can assume that regions with more focus on research and development activities could be awarded by higher labour productivity and potential higher economic growth. In our research we have indentified factors with potential effect on labour productivity based on the data for NUTS 2 regions in EU. Our results strongly suggest that research activities as well as appropriate infrastructure could both play important role in increasing labour productivity in the region. More scientific publications as well as more patent applications are positively correlated with higher labour productivity. The same is true for gross domestic expenditure on R\&D (GERD) financed by higher education. Thus, we can say that better research performance at higher education institutions or research institutions in the region could increase labour productivity. Moreover, higher education institutions could have positive effect on labour productivity also by increasing the education level in the region. This assumption has been also supported by our results.

We also examined selected indicators related to research and development in NUTS 2 in the Czech Republic and Slovakia. As expected regions, Praha, 
Bratislavský kraj and Strední Čechy significantly outperform outer regions in most of the indicators. These three regions have been also classified together in the same cluster based on the results of cluster analysis. While regions in Slovakia significantly lag behind the leading region in almost every dimension this difference is rather smaller in the Czech Republic.

Our results could have several important implications for EU regional policy and public support of higher education and research education at national and supranational level. The support of research and development at regional level seems to be important in order to further increase labour productivity and maintain regional economic growth. Hence, universities and other higher education institutions are one of the most important subjects in these terms. The potential of these institutions for improving regional development is very high. This represents one of the main challenges for national and the EU regional development policy. However, when talking about this support it is inevitable to distinguish those regions that performing very well in this filed from those that are significantly lagging behind. The differences between regions seem to be still very significant.

Acknowledgements. This research was supported by the Slovak Research and Development Agency (APVV), APVV-14-0512 "Universities and regional development".

\section{References}

1. Al Raee, M., Ritzen, J., de Crombrugghe, J.: Innovation policy \& labour productivity growth: Education, research \& development, government effectiveness and business policy. MERIT Working Papers. 019 (2017)

2. Anselin, L., Varga, A., Acs, Z.: Local geographic spillovers between university research and high technology innovations. Journal of urban economics, 42(3), 422-448. (1997).

3. Balog, M. et al.: Inovatívne Slovensko - východiská a výzvy. (In Slovak) Slovenská inovačná a energetická agentúra, Bratislava (2013).

4. Bogliacino, F., Pianta, M.: The impact of innovation on labour productivity growth in European industries: Does it depend on firms' competitiveness strategies? Working Papers Series on Corporate R\&D and Innovation. 13 (2009).

5. Bronzini, R., Piselli, P.: Determinants of long-run regional productivity with geaographic spillovers: The role of R\&D, human capital and public infrastructure. Regional Science and Urban Economics. 2(39), 187-199 (2009)

6. European Commission: National/Regional Innovation Strategies for Smart Specialisation (RIS3),http://ec.europa.eu/regional_policy/sources/docgener/informat/2014/smart_speciali sation_en.pdf, last accessed 2017/10/31.

7. European Commission: Research and innovation. Pushing boundaries and improving the quality of life, https://publications.europa.eu/sk/publication-detail/-/publication/ba202c94aa5d-11e6-aab7-01aa75ed71a1/language-en, last accessed 2017/31/10.

8. European Commission: What is Smart Specialisation?, http://s3platform.jrc.ec.europa.eu/ what-is-smart-specialisation-, last accessed 2017/11/03. 
9. Guellec, D., van Pottersberghe de la Potterie, B. R. D: Productivity Growth. OECD Economic Studies. 2(12), 103-126 (2001)

10. Hall, B. H., Lotti, F., Mairesse, J.: Evidence on the impact of R\&D and ICT investments on innovation and productivity in Italian firms. Economics of Innovation and New Technology. 3(22), 300-328 (2013)

11. Kendrick, J. W., Vaccara, B. N.: New Developments in Producitvity Measurement. University of Chicago Press, Chicago (1980)

12. Kremer, J. F., Below, K.: Innovative Capabilities and Market Performance: The European Union in International Comparison. The Jean Monnet/Robert Schuman Paper Series. 12 (7) (2012).

13. Martín, C., Mulas-Granados, C., Sanz, I.: Spatial distribution of R\&D expenditure and patent applications across EU regions and its impact on economic cohesion/Distribución espacial de los gastos en I+ D y de patentes en las regiones europeas y su impacto en la cohesión económica. Investigaciones regionales, (6), 41 (2005).

14. McCann, P., Ortega-Argilés, R.: Transforming European regional policy: a results-driven agenda and smart specialization. Oxford Review of Economic Policy, 29(2), 405-431. (2013).

15. Wei, S. H., Wu, G. S.: An empirical study on spatial distribution and its changing trends of regional R\&D expenditure in China. R\&D Management, 13(1) (2008)

16. Zachariadis, M. R. D.: Innovation and technological progress: A test of Schumpeterian framework without scale effects. Canadian Journal of Economics 36, 566-86 (2003)

17. Zhong, W., Yuan, W., Li, S. X., Huang, Z.: The performance evaluation of regional R\&D investments in China: An application of DEA based on the first official China economic census data. Omega, 39(4), 447-455 (2011). 